\title{
カキの果実重量に影響する要因に関する研究
}

\author{
岸本修* \\ （東京大学農学部付属虔場）
}

\section{O. Kisнimoto : Factors affecting fruit weight of Japanese persimmons (Diospyros Kaki Linn. f.)}

\section{Summary}

1. This investigation was carried on from 1960 to $1963 \mathrm{w}$.ith three varieties of Japanese persimmons (Jiro, Monpei and Hiratanenashi) to make clear the main factors connected with the yearly change of the average individual fruit weight of a tree. Fruits were thinned usually to one per bearing shoot in July of each year, except for on some of trees in 1963.

2. When the correlation was observed between shoot length and leaf area, and between leaf number and leaf area respectively, its coefficient was higher in the former than in the latter. Consequently, fruit number per one meter length of shoot was employed as an indicator of fruit load on a tree, dividing the total number of fruits by the total length of non-bearing and bearing shoots.

3. A significant negative correlation was always found between fruit load of a tree and average

\section{I. 緒 言}

収穕時の果実重量は，1果当たりの葉数 (葉面積), 種子数牤よび結果枝の長さなどが増大するに伴なつて増 加する場合の多いことが従来の研究 $(3,5,6,9,11,12,16,17,18,22$, 24)で明らかにされている。しかし，果重に影響するこれ らの諸要因の相互関係や，あるいは，その影響力の比較 についての実験成績はほとんどみあたらない。そこで本 研究はカキを材料としてこれらの点を明らかにしようと したものである。

本研究を行ならにあたり, 終始, 懇篤な指導を賜わつ た東京大学杉山直儀教授, 実験実施に多大の援助を与え られた付属農場長松尾孝嶺教授, 二宮果樹園主任佐藤幹 夫講師に深謝の意を表する。調査は, 文部技官今泉定作, 果樹園職員脇一夫, 脇信夫, 欈川照子の諸氏の助力に負 うところが多く謝意を表する。

\section{II. 材料および方法}

1960 年から 1963 年までの 4 か年にわたり, 東京大

本論文の要旨は 1964 年度園芸学会春季大会において 発表䅐在 農林省園芸試験場

1964 年 10 月 6 日受理 individual fruit weight. However, a significant positive correlation existed only occasionally both between bearing shoot length and average individual fruit weight, and between seed number of a fruit and average individual fruit weight. Therefore, the fruit load of a tree seemed to have a deeper connection with the average individual fruit weight than the length of a bearing shoot and the seed number of a fruit.

4. Average individual fruit weight varied from 150 to $250 \mathrm{~g}$ in the yearly change of the same tree as well as among the different trees of the same year. The variation coefficient expressed as a measure of dispersion of individual fruit weights was 7 to $15 \%$ regardless of the fruit load. A significant positive correlation was always found between fruit load of a tree and its yield.

学農学部付属農場二宮果樹園（神奈川県二宮町）飞栽植 の約 30 年生の次郎, 紋平, 平核無の延 104 本を供試 して本調査を行なつた（第 2 表)。これらの供試樹の特 性はすでに 1963 年に報告(14) したと沶りであるが，1樹 当たりの着果数に関与する摘果はいずれの年も 7 月上旬 に行ない, その程度は, 1960～'62 年には 1 結果枝 1 果 とした。しかし，1結果枝 1 果の摘果では隔年結果防止

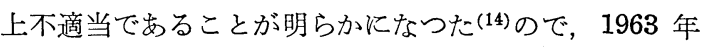
には一部の樹で摘果の程度を変更した。すなわち，果実 は大部分がある範囲の長さの枝から生産されるので, 結 果枝, 不結果枝の別なく一定の長さの枝を収量構成枝々 仮称し，この収量構成枝を摘果の基準にすることが合理 的であると推定した。その枝の長さの範囲は次郎，平核 無は 6 25cm, 紋平は 11 30cm である。1963 年に は一部の樹では収量構成枝 $2 \sim 3$ 本当たり 1 果を残す摘 果をした。

このような方法で摘果を行なつた供試樹について，収 穫時に樹別に結果枝, 不結果枝の別なく全部の新梢につ いて，その長さを測定するとともに，収穫果数および収 量を調查し, それぞれの平均果重を求めた。各品種の代 


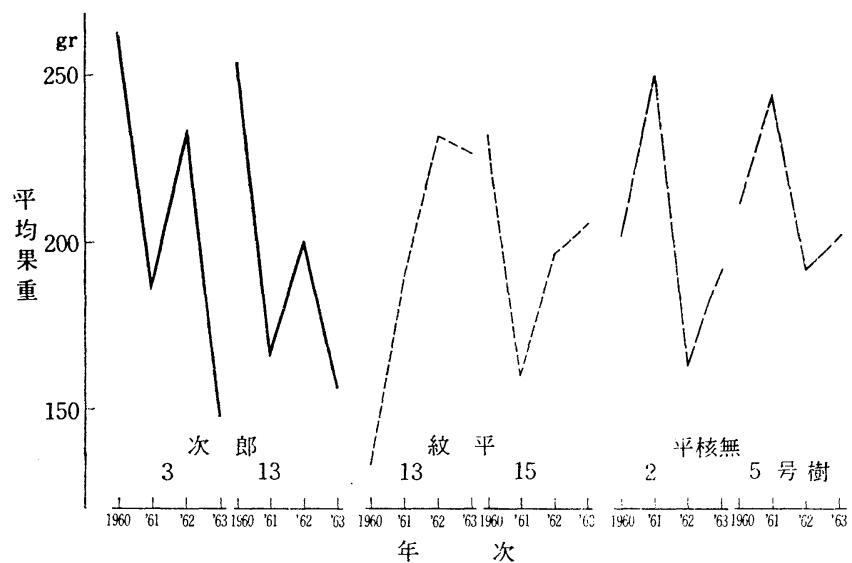

第 1 図同一樹の平均果重の年次別変異（次郎, 紋 平，平核無の各 2 本)

表的な樹 2 本ずつを例として平均果重の年による变化を 図示すると第 1 図のと沏りで同じ樹でも年によつて 150 ～250g に変化した。このよ5汇平均果重が年によつて 大きく変化する原因を本研究で明らかにしようとした。

まず, 1961 年の収穫洔に, 結果枝の長さと果重との 関係を，各品種 2 3 樹，計 8 樹につき調査した。1962 年には，各品種の数本の樹について，樹全体または主枝

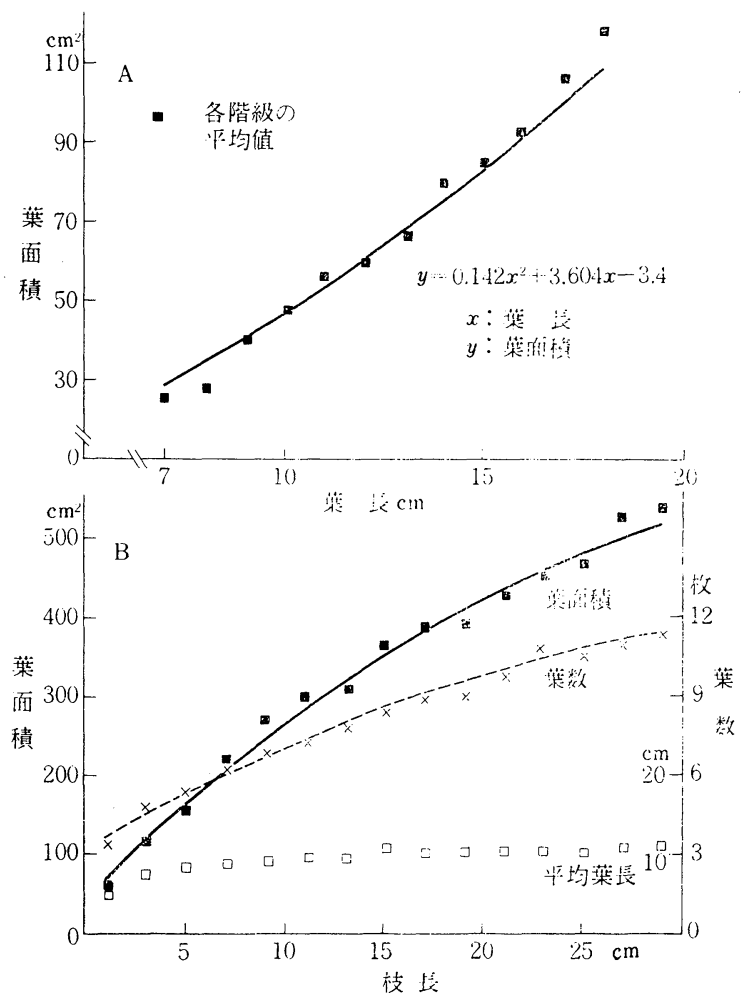

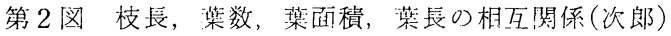

ごとに 50〜200 果を避び前年と同漛な調南 を行なつた。

1963 年には種子数と果重との関係を，3 品種の収穫時に任意に選出した果実について 調查した。ほかに，同年 7 月上旬に摘果した 上記 3 品種（次郎, 紋平, 窗有) の果突を, 1 樹当たり 200 果の制含で，またさらに 8 月上句に一部の樹の 30 100 果につき種子 数を調查した。

1961 年の装に, 前記の供試 3 品種ととも 汇約 30 年生の富有呫上び約 10 年生の平核 無について，任意に潠んだ枝 400 本を用い， 枝長，葉長特よび葉数の相互関係を調査した。 葉長々葉面積の関係については，1960～'62 年の間に，品種ごとに，旮れぞれ 620 枚の葉を用いて 調查した。葉面積の算出方法としては既報 ${ }^{(14)}$ の台形公 式を利用した。次郎を例として，枝長，葉数，葉面積の 相互関系をみると第 2 図のと新りである。すなわちA図 は葉長と葉面積の関係を示し，B図は，枝長に対する葉 数と葉面積の関係を示したものである。葉長の増加につ れて葉面積は著しく增し， $1 \sim 30 \mathrm{~cm}$ の枝長では菜面積 の增加率が葉数の增加率より大であつた。

A, B 図に示した葉長, 葉面積, 葉数, 枝長の相互 第 1 表 葉長, 葉面積, 葉数, 枝長の相互 関係の実験式

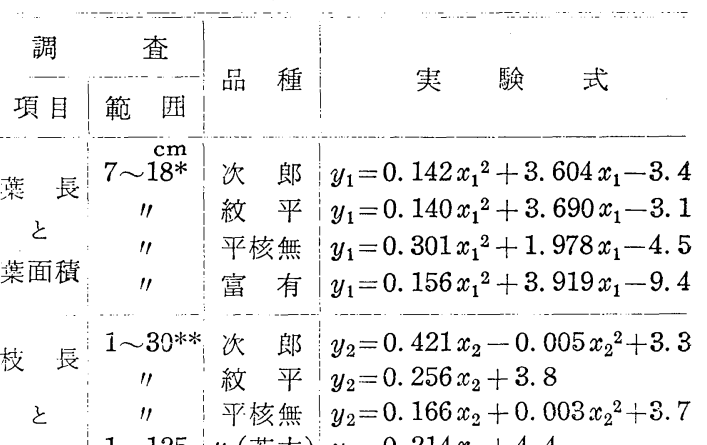

1 125 "(若木) $y_{2}=0.214 x_{2}+4$.

葉 数 $1 \sim 30$ 富 有 $\mid y_{2}=0.246 x_{2}+3.2$

的 $\mid 1 \sim 30 * *$ 次 郎 $y_{1}=24.39 x_{2}-0.268 x_{2}{ }^{2}+46.7$ 枝舞 1 紋 平 $y_{1}=28.84 x_{2}-0.317 x_{2}{ }^{2}$

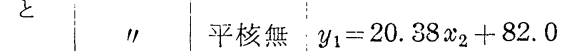

柴血積 $1 \sim 125$ 川(若木) $y_{1}=18.13 x_{2}+108.2$ $1 \sim 30$ 䈏 有 $y_{1}=14.61 x_{2}+114.7$

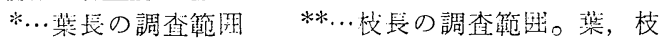
長とも極大極小は除いた $x_{1}$ ‥染長 $(\mathrm{cm})$

$x_{2} \cdots$ 枝長 $(\mathrm{cm}) \quad y_{1} \cdots$ 荣面䅡 $\left(\mathrm{cm}^{2}\right) \quad y_{2} \cdots$ 莱数 $($ 枚 $)$ 
第 2 表 枝 $1 \mathrm{~m}$ に対応する葉数*および 葉面積*の品種間比較

\begin{tabular}{|c|c|c|c|c|c|c|c|}
\hline \multirow[b]{2}{*}{ 品 種 } & 調査樹 & 葉 & & 数 & 葉 & 面 & 積 \\
\hline & 数** & $\begin{array}{l}\text { 平均 } \\
\text { 值 }\end{array}$ & $\begin{array}{l}\text { 標準 } \\
\text { 偏差 }\end{array}$ & $\begin{array}{l}\text { 変異 } \\
\text { 係数 }\end{array}$ & $\begin{array}{l}\text { 平均 } \\
\text { 值 }\end{array}$ & $\begin{array}{l}\text { 標準 } \\
\text { 偏差 }\end{array}$ & 変異 \\
\hline 郎 & 40 & 70.1 & $\begin{array}{l}\text { 枚 } \\
7.39\end{array}$ & $\begin{array}{l}\% \\
10.5\end{array}$ & $\begin{array}{r}\mathrm{cm}^{2} \\
2,583\end{array}$ & $\begin{array}{r}\mathrm{cm}^{2} \\
186.3\end{array}$ & $\begin{array}{r}\% \\
7.2\end{array}$ \\
\hline 敉 平 & 38 & 59.3 & 5.54 & 9.3 & 2,802 & 163.4 & 5.8 \\
\hline 平核無 & 26 & 55.3 & 4.25 & 7.6 & 2,789 & 153.9 & 5.5 \\
\hline
\end{tabular}

$* \ldots 1$ 樹の全葉数（全葉面積） $\div$ 全枝長

$* * \ldots 1960 \sim$ ～ 63 年の間の延べ調査本数

関係の品種間比較のために，実験式を第 1 表にむとめ た。その結果は，いずれの品種に拈いても次郎と同様な 関係を示し，枝長は葉数よりも葉面積との相関が高い。 したがつて，本研究では 1 樹当たりの結果量（結果の程 度）の多少の表現に枝 $1 \mathrm{~m}$ 当たりの収穫果数を用いる ことにした。参考のために枝 $1 \mathrm{~m}$ に対応する葉数, 葉 面積を第 2 表に示したが，これらは落葉が起こらなかつ たものと仮定しての值である。 3 品種に共通なことは, 葉数の変異係数が葉面積のそれよりも常に大きいことで あつた。

\section{III. 実 験 結 果}

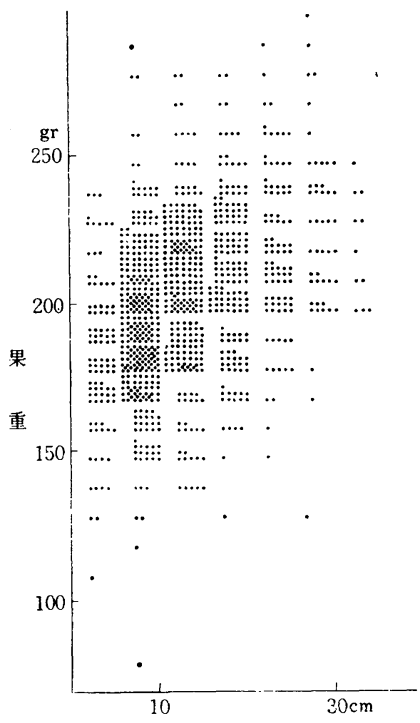

次郎 -18 号 $r=0.411 * * *$ $y=1.43 x+181.3$

\section{1. 果重と結果枝の長さとの関係および果 重の分散}

収穫時の個々の果重と結果枝の長さ（本論文の場合, 結果枝は収穕果のあつた枝と限定する)との関係を 1961,

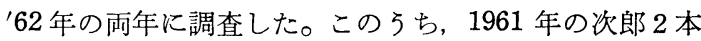
と紋平 1 本についての調查結果を第 3 図に示した。次郎 18 号樹拉よび 4 号樹では, 両樹ともに結果枝が長くな るにつれて, 個々の果重が重くなるという正の相関がみ られた。それらの直線回帰を求めると枝が $1 \mathrm{~cm}$ 長くな るにつれて, 約 $1 \mathrm{~g}(0.74 \sim 1.43 \mathrm{~g})$ の果重が増加した。 それに対して, 紋平 16 号樹では結果枝の長さと果重の 間に相関がみられなかつた。相関の認められた次郎 18 号樹と 4 号樹の平均果重はそれぞれ $202 \mathrm{~g}$ と $146 \mathrm{~g}$ であ り，また $200 \mathrm{~g}$ 以上の果実の全収穫果中に占める割合は それぞれ $53 \%$ と $1 \%$ であつた。これら 3 樹に共通な ことは, 同じ長さの枝でも約 $100 \mathrm{~g}$ の果重の分散のある ことであつた。しかし，同じ長さの結果枝でも，次郎の 例でみられるよ5に，樹によつては $200 \mathrm{~g}$ 以上の果実が 形成される確率は異なるのである。このことは, 果重に影 響するものは同一樹内の結果枝の長短よりも，樹全体の 扣かれた条件がより大きな関係をもつものと考光られる。

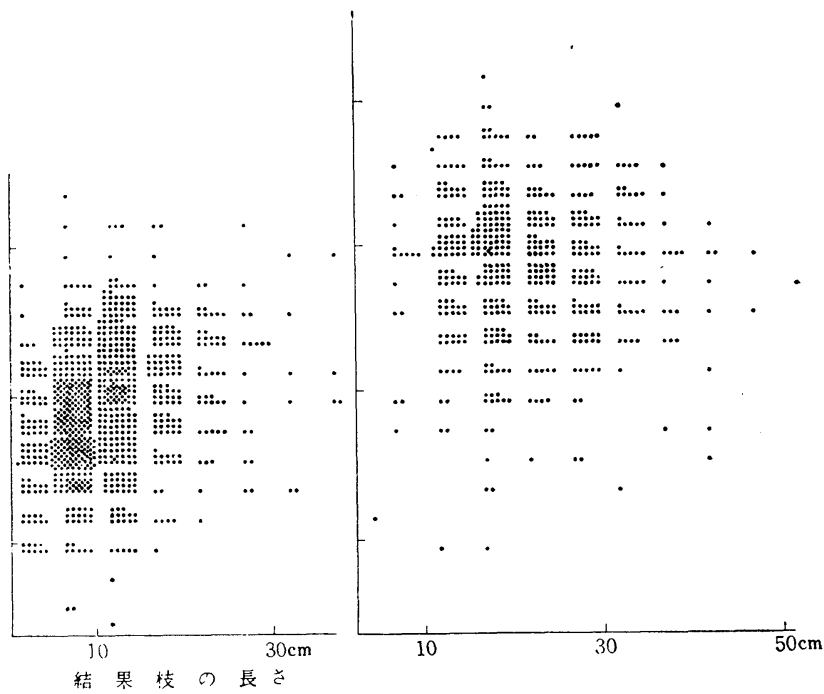

次郎 -4 号 $r=0.303^{* * * * *}$ $y=0.74 x+136.5$

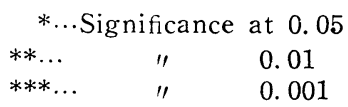

紋平-16 号 $r=-0.008$ N.S.

$x \cdots$ 枝長 $(\mathrm{cm})$

$y$...果重 $(\mathrm{g})$

第 3 図果重と結果校の長さ(1961 年の全収穫果の調査) 


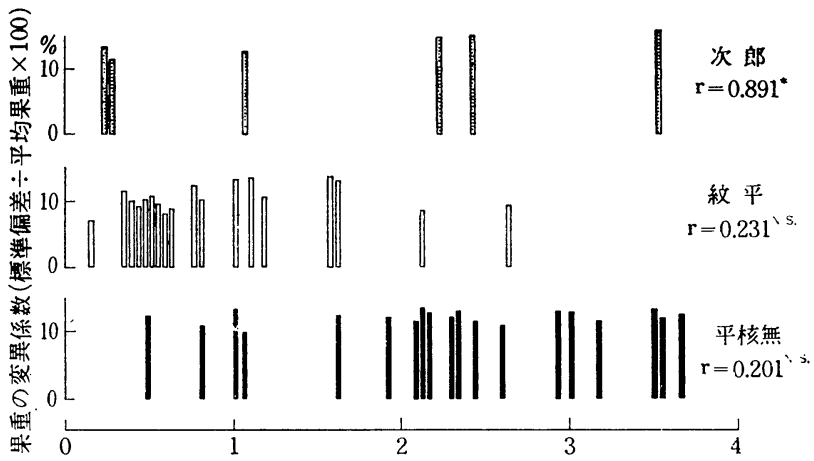

枝 $1 \mathrm{~m}$ 当たり果数（収穫果数 $\div$ 全枝長）

第 4 図 枝 $1 \mathrm{~m}$ 当たり果数と果重の分散（変異係数） 果重の変異係数が 1 樹当たりの結果量の増減に夙連し てどう変るかを調查したのが第 4 図である。1樹当たり の結果量（結果の程度）の多少の表示には，1樹の全収 穫果数をその樹の新梢の長さの総計（全枝長）で割つた 值を枝 $1 \mathrm{~m}$ 当たり果数として用いた。果重の変晎係数 と枝 $1 \mathrm{~m}$ 当たり果数との間には, 調查. 数の少ない次郎 に有㤎の正の相関がみられたが，てれ以外の品種では相 関がなく，結果量の多少にかかわらず 7〜15\%の範閒 であつた。ただしこれらの数值は 1 結果枝 1 果とするな どの摘果をしたことの效果も含まれているかもしれな w。

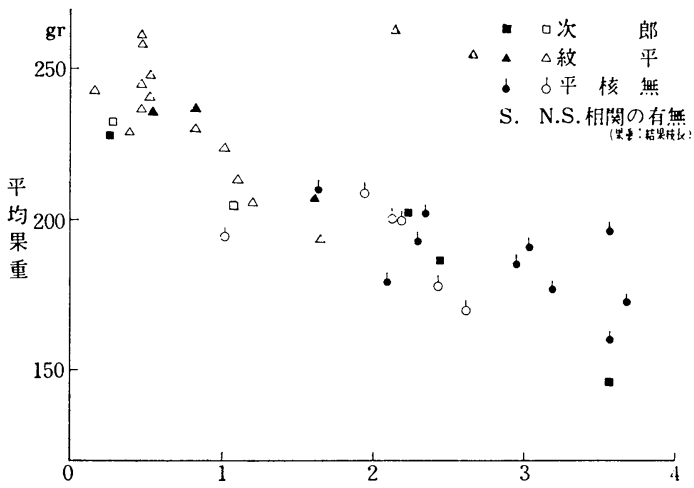

第 5 図 結果枝長と果重との間の相関と枝 $1 \mathrm{~m}$ 当心り 果数との関係（結果枝長と果重との問の相関が有急 な場合と有意でない場合を区別して表示してある）

前述のように, 結果枝の長さと果重との間の相関関係 には有意性がある場合とない場合がみられたので，その 原因を明らかにするために，第 5 脑をなとめた。すなわ ち, 結果枝の長さと果重との間の相関の有意性につい て，その有無の区別を明らかにするとともにそれれらと 結果量の割合（枝 $1 \mathrm{~m}$ 当たり果数）との関係を示した。 品種別に，有意性の有無の点で多少の例外はあるが，枝
$1 \mathrm{~m}$ 当たりの果数が多くなるにつれて，果重と 結果枝の長さとの間に相関が涊められる場合が 多かつた。

\section{2. 種子数と果重}

1963 作の收檴時に，任営に選んだ果実の重 さと種子数の関係を及たのが，第 6 図 $\mathrm{A}$ であ る。次郎と富有では, 雨者の間に有意の正の相 四があり，南線回帰を求女ると種子 1 個の增加 に刘して約 $5 \mathrm{~g}$ の果重の增加がみられた。しか し，紋平では，両者の間に有意の相関がなかつ た。 3 品種に共通なことは同じ種子数でも果重 の分敬は約 $100 \mathrm{~g}$ まつた。

头均果重が年により，樹によつて哭なつたので，その 原因を知るために，樹別の平均種子数と平均岀重の関係 を調べた。カキの品種の種子数の表示に摘果した果実を 用いた皶告(21)を参帣にして，1963 年 7 月上旬に摘果し た棵実と、さらに，一部の樹で 8 月上旬に摘果した果実 の種子数の調往を行なつた。7月と 8 月の種子数の值に 有总差を認めなかつたので，これらの数値を一応その樹 の平均種子数とし, その作の平均果重との相関をみたの

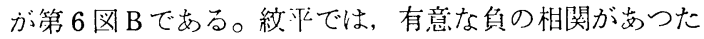
が，次郎扣よび富有では有意の相関は認められなかつ だ。

\section{3. 結果量と平均果重}

1 樹の光合成能力と関連する新梢の長さの総計を基に した枝 $1 \mathrm{~m}$ 当たりの収穫果数と平均果重の関係をみた のが第 7 図である。A図は, 次郎の年間差異を示した が，4年間を通じてみると, 平均果重と枝 $1 \mathrm{~m}$ 当たり 果数は㐿の相関を示した。同様なことを，品種間で比較 したのが B図であり，供試した 3 品種とも $0.1 \%$ 水準 で有甞な負の相関を示した。

一般的に, 結果量が少なくなれば平均果重の增加を示 すのであるが，第 7 困を詳細にみると平均果重の最大の ものが必らずしも結果量が最少のものとは限らないし, また，結果㗨が少なくても平均果重の小さい場合もあつ た。

\section{4. 結果量と収量}

1 樹の全枝長（新梢の長さの総計）で収量を割つた值 を，枝 $1 \mathrm{~m}$ 当たり収量とし，それと枝 $1 \mathrm{~m}$ 当たり果数 との関係を第 8 図に示した。A図は次郎の年間差異であ ろが，4年間を通じて正の相関がみられた。同様にし て品種間比較を B 図にみると 3 品種とも， $0.1 \%$ 水準で 有意な正の相関を示した。これは果実収量は収篗果数に 依存する割合が大であること资示している。

以上のことを平均果重の推移と対比させて考えると， 


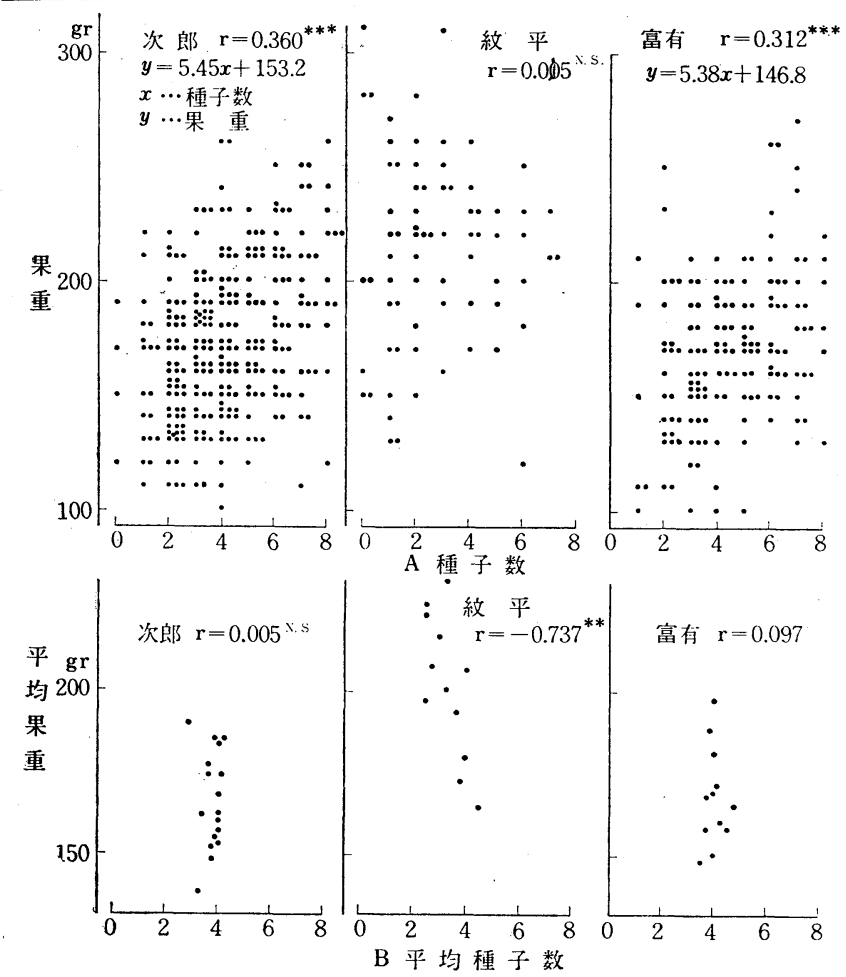

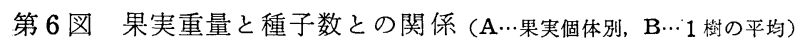

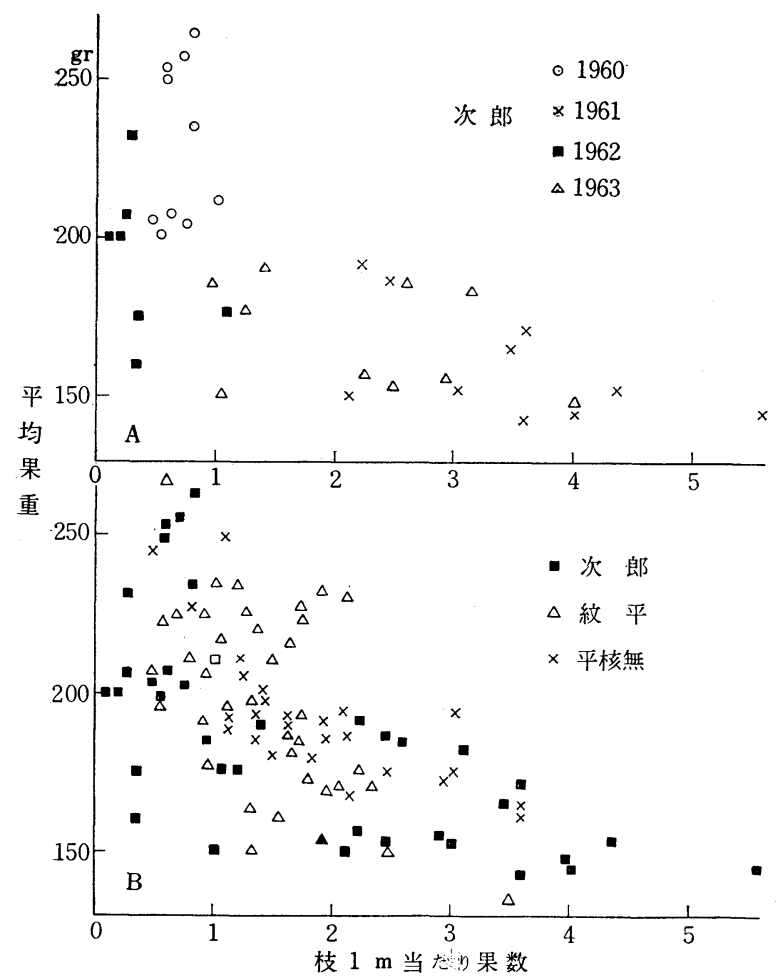

第 7 図平均果重と枝 $1 \mathrm{~m}$ 当たり果数との関係

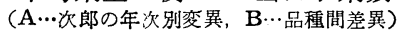

第 7 図では, 結果量を示す枝 $1 \mathrm{~m}$ 当たり果 数が多くなれば平均果重の減少することを示 したが，第 8 㘠では，そのようなことを考慮 に入れても 1 樹当たりの収量は 1 樹当たりの 結果量と正の相関にあることを示している。

\section{IV. 考察}

果実重量に影響する要因に関する研究は, これまで，同一樹内の果重の分散を対象と し，また，要因を個別的に研究する場合が多 かつた。本研究に括いては, 果重が樹全体と して年により，樹により，どのように変化し たかを $2 ， 3$ の要因と関連させて調查したの で，その中で特に平均果重が何によつて影響 されるかということに重点を置いて考察を進 めた。

果実に影響する要因として，結果枝の長さ， 種子数执よび 1 樹当たりの結果量の多少（枝 $1 \mathrm{~m}$ 当たり果数) を選んだ。結果枝の長さと 果重の相関関係の有意性は, 枝 $1 \mathrm{~m}$ 当たり 果数の多い場合，すなわち，1樹当たりの結 果量の多い場合に高く認められ, 枝 $1 \mathrm{~m}$ 当 たり果数の少ない場合に低い傾向にあつた。 このことは持そらく後者では果実の肥大に関 係の女る光合成生産物が必要限界以上に供給 されるからと思われる。

種子数と果重の関係については，これまで にも正の相関があるとする報告 $(1,4,6)$ と，そ れが認められないという報告( ${ }^{(9)}$ とがあり，本 実験の結果に沏いても両方の場合を含んでい た。しかし, 供試 3 品種に和いては, 平均果 重と平均種子数の間に正の相関はみられなか つた。

要するに以上の結果からみて, 結果枝の長 さや，種子数は，果重に影響する要因の中で も他の要因によつて容易に影響を受ける副次 的なものと思われる。

これらに比して, 平均果重と常に相関のあ つたのは 1 樹当たりの結果量の多少を示す枝 $1 \mathrm{~m}$ 当たり収檴果数のみであつた。このこと から平均果重に影響する主要因は 1 樹当たり の結果量の割合であると推定した。

果実に影響する要因の個別的研究は多数報 告され，乙かも，その結論が多岐にわたつて いるので，これらを要因相互の比較の面から 考学る。要因の個別的な研究の中で一致した 


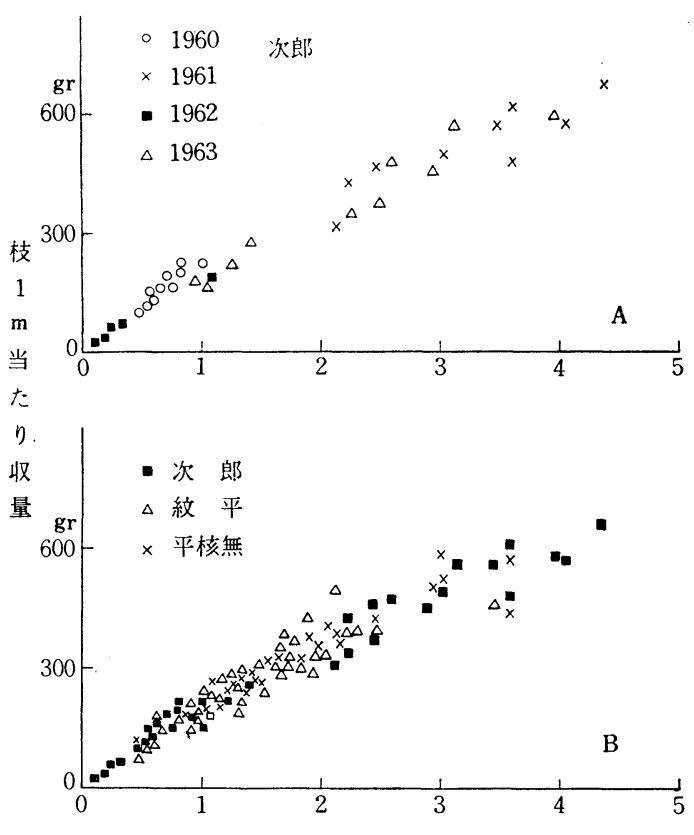

枝 $1 \mathrm{~m}$ 当たり果数

第 8 図枝 $1 \mathrm{~m}$ 当たり果数と収量の関係 $(\mathrm{A}$ ：次郎の年次別変異 $\mathrm{B}$ : 品種間差異)

結論が得られたのは，1果当たり葉数と果重の間に正の

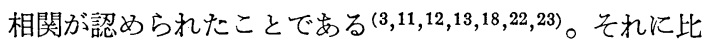
して，たとえば，結果枝が長いほど果実は大きくなると いう報告 ${ }^{(17,23,24)}$ は多いが，両者の間関係がないとい 弓報告(11)もあり，異なる結論もみられるが，これはす でに述べたように，本実験の結果，結果枝の長さと果重 との相関関係の有意性は 1 樹当たりの結果量の割合の多 少によつて異なる傾向が示された（第 5 図）ことによつ て理解されよ5。すなわち，1樹当たりの結果量が多け れば，結果枝の長さと果重に相関が認められ，少なくな れば両者の間に相関がなくなる。このことは, 結果枝の 長さが果重に影響を与兄るのは 1 樹当たりの結果量がか なり多いというょうな，ある特定の条件の範囲内で生じ ることである。これに対して，前記の 1 果当たり葉数と 果重に正の相関がみられたのは，1果当たり葉数は本研 究で果重に影響する主要因と推定した枝 $1 \mathrm{~m}$ 当たり収 穫数と同様な意味を有するものであり，ぬた，それは主 要因が副次的要因の影響を受け難いことを示するのと考 えられる。

これらの現象は, 果実重量に影響する要因を研究する 際に重要なことと思われる。すなわち，副次的要因の結 果枝の長さと果重の相関は主要因と推定した枝 $1 \mathrm{~m}$ 当 たり果数の增減によつて異なつた結果を示したことであ る。このことから, 副次的な要因を研究する際には常に
それよりも上位の要因を含めた考察もしくは記録が 必要であると考えられる。

\section{V. 摘 要}

1. 本調查は 1960 1963 年に, カキの 3 品種次 郎，紋平拉よび平核無について，1樹当たりの果実 1 個平均重の年変異の主な原因を調べるために行な つたものである。果実の摘果は 1963 年の一部の樹 を除いて，毎年 7 月上旬に 1 結果枝当て 1 個の割合 でなされた。

2. 新梢の長さと葉面積の間，および葉数と葉面 積の間の相関をそれぞれ求めたのに，前者に招いて は，後者に打けるよりも高い係数を示した。したが つて1樹当たりの結果量の多少をあらわす指標とし て，結果枝拈よび不結果枝を含めて全枝長で総果実 数を除した値すなおち新梢 $1 \mathrm{~m}$ 当たりの着果数 を用いた。

3. 1 樹当たりの結果量（枝 $1 \mathrm{~m}$ 当たりの収穫 果数）と果害 1 個の平均重との間には常に有意の負 の相関がみとめられた。しかしながら，結果枝の長 さや含種子数と個々の果実重量との間には，有意の 正の相関が常にあるとは限らず，ときに存在する程 度であつた。

したがつて，1樹当たりの結果量は，結果枝の長さや 含種子数よりも, 果実 1 個の平均重に対し, 常に有力に 作用した。

4. 果実 1 個の平均重は, 同一樹に扮いても年によ り，また同じ年であつても樹が異なれば，150～ $250 \mathrm{~g}$ の 間で変異した。果重の分散を示す变買係数は結果量の多 少にかかわらず 7〜15\% であつた。1樹当たりの収量 は, 常に結果量（結果数）との間で有意の正の相関を示 した。

\section{参 考 文 献}

1. 浅見与七・胡昌儎. 1928. 梨に於ける果実の大き さと二, 三の形質との相関関倸に就て。農及園. 3 ( 3 ) : $247 \sim 258$.

2. 渥美樟雄・中村三夫. 1959. 力キ果の蒂の生理生 態学的研究 (第 1 報). 園学雑. 28 ( 3 ): 170 176.

3. Chandler, W.H. \& A. J. Heinicke. 1926. The effect of fruiting on the growth of Oldenburg apple trees. Proc. Amer. Soc. Hort. Sci. $23: 36 \sim 46$.

4. 遠藤政太郎。1937。葡萄果粒の大きさに及ぼす種 子の影響. 園研集録. $2: 147 \sim 155$.

5. HALleR, M. H. \& J. R. MAGNESS. 1925. The relation of leaf area to the growth and composition of apples. Proc. Amer. Soc. Hort. Sci. $22: 189 \sim 196$. 
6. 羽鳥信吉. 1927. 久保柿に於ける種子の形成が果 実の形質に及ぼす影響に就て。農及園.2（3）: $249 \sim 264$.

7. 平野 暁・森岡節夫・長門雄平. 1958. ビワの種 子数, 葉数, 花房の大きさなどと果実重量との関 係. 千葉農試報告 $3: 64 \sim 68$.

8. 岩崎藤助. 1961. カンキッの隔年結果防止に関す る研究 (第 4 報). 園学雑. 30 ( 2) : 103 110.

9. 梶浦実. 1934. 柿の Metaxenia に関する研究 (第 1 報). 園学雑. 5 ( 2 ): 259 271.

10. 梶浦 実編. 1958. カキ, クリ。農文協.

11. 川口正英. 1929. 桃の果実に関する二, 三の調査. 農及園. 4 ( 6 ）：694〜699.

12. ……1933. 温州蜜柑の果実の発育に対する 葉の影響. 農及園. 8 ( 8 ) : 1903 1908.

13. - - . 佐宗久雄. 1937. 日本梨に於ける葉面 積と果実の発育. 園学雑. 8 ( 1 ) : 189 192.

14. 岸本 修. 1963. 力キの摘果の基準に関する研究. 園学雑. 32 ( 3 ) : 168 174.

15. MAGGS, D. H. 1960. The effect of number of shoots on the quantity and distribution of increment in young apple-trees. Ann. Bot. N. S. $24: 345 \sim 355$.
16. MAgness, J. R., F. L. Overley \& W. A. LuCE. 1931. Relation of foliage to fruit size and quality of apples and pears. Wash. Agr. Exp. Sta. Bull. 249.

17. 長田 実. 1927. 柑橘に関する試験成績. 園芸講 演集. $91 \sim 95$.

18. 新津 宏・梶浦 実. 1933. 桃の葉面積と果実と の関係. 園学雑. 4 ( 1 ) : 81〜87.

19. 1935. 再び桃の摘果に就い て. 園芸之研究. $31: 6 \sim 16$.

20. 大垣智昭 - 藤田克治 - 伊東秀夫. 1963. 温州 ミカ ンの隔年結果に関する研究 (第 3 報). 園学雑. 32 ( 1 ) : 13 19.

21. 大崎 守. 1935. 柿に関する調査. 園芸之研究. $31: 39 \sim 54$.

22. 佐宗久雄. 1937. 柿に於ける葉面積と果実の発育. 園芸之研究. $33: 25 \sim 33$.

23. 佐藤公一. 1946. 葡萄の葉数と結果との関係。農 及園. 21 ( 7 ) : 295 296.

24. 重田利夫・安延義弘. 1958. 柿の果実に関する調 査. 昭 31 年度果樹研究年報 : 246 247.

25. 傍島善次. 1959. 柿. 朝倉畫店.

抄録

\section{受光量がリンゴ幼樹の炭水化物生産量に及ほすす影響}

リンゴの台木品種 MM 106 の 1 年生樹を, 自然光下 および粗いネットを用いて受光量を自然光の 78,41 , $24 \%$ に調節した条件下に扣き，樹体内の炭水化物含量 の変化を次の 6 時期にわたつて調査した。

S. 1-萠芽期, S.2-展葉開始期, S. 3-伸長開始期, S. 4伸長中期, S. 5-伸長停止期, S. 6-落葉期。

結果は次のように要約される。

1）樹体の総乾物生産量は受光量に著しく左右された が，炭水化物組成には，処理による差がほとんどみられ ず, 新梢内のでんぷん, 新根内のフロリジン拈よびへミ セルローズ含量に有意差がみとめられるのみであつた。 すなわち，新梢内のでんぷんは自然区の方が生長期の大 部分を通じて $24 \%$ 区よりも少なく, 新根のフロリジン とへミセルローズはその逆であつた。

2) S.1. では, 旧梢から炭水化物が奪われたがその 減少量は, 受光量の違いにほとんぞ影響されなかつた。
しかし，その回復は受光量に左右され，自然光下では萠 芽期の状態まで回復するのに 46 日しかかからなかつた が，しや光の程度が強いほど遅れ，24\% 区では 108 日 かかつた。なお, 有効な炭水化物量の回復に要した積算 光合成量は，4区ともほぼ同量であつた。

3） S. 3〜S. 4 では, 新しく生長した部分の総炭水化 物増加量および残渣の乾物增加量は, 受光量と顕著な関 連がみられた。しかし，その増加率には処理間の差はほ とんどなかつた。

以上の結果から, 生長期に打ける樹体内の炭水化物含 量は, 光の影響から独立している時期と, これに左右さ れる時期があると考学らる。

(杉山操子)

PRIESTLEY, C. A. 1963. The carbohydrate resources of young apple-trees under four levels of illumination. Ann. Bot. (Lond.) $27: 435-446$. 